\title{
Социально-экономическая география
}

УДК 911.375

DOI: https://doi.org/10.26456/2226-7719-2021-4-57-64

\section{БЛАГОУСТРОЙСТВО В МАЛЫХ ГОРОДАХ ТВЕРСКОЙ ОБЛАСТИ: \\ ТЕРРИТОРИАЛЬНЫЕ И ИНСТИТУЦИОНАЛЬНЫЕ АСПЕКТЫ ${ }^{1}$}

\section{И.П. Смирнов, А.А. Смирнова}

ФГБОУ ВО «Тверской государственный университет», г. Тверь

Статья посвящена проблеме благоустройства малых городов. На примере семи малых городов Тверской области рассмотрены количественные итоги их участия в различных программах благоустройства (институциональный аспект), а также проведен анализ микрогеографии реализованных проектов (территориальный аспект). В качестве инструментов благоустройства выбраны региональная программа Тверской области по формированию комфортной городской среды, Программа поддержки местных инициатив, Всероссийский конкурс лучших проектов создания комфортной городской среды. Города различаются в активности использования названных программ. Отмечена также дифференциация разных зон города - центра, полупериферии, периферии - по числу реализованных проектов. Предложены три территориальные модели благоустройства в зависимости от того, в какой части города сконцентрирована большая часть проектов.

Ключевые слова: малье города, Тверская область, благоустройство территорий, комфортная городская среда, программа поддержки местных инициатив

Введение. Рост внимания к качеству городской среды в малых городах со стороны государства ознаменовался принятием в конце 2016 г. приоритетного проекта «Формирование комфортной городской среды». Согласно паспорту проекта, результаты от его реализации масштабны и разноплановы: здесь и создание тематической нормативно-правовой базы в субъектах РФ, и обучение региональных представителей, и методическое обоснование индекса качества городской среды, и финансирование конкретных мероприятий по благоустройству. В настоящее время федеральная повестка по созданию комфортной среды заключена в рамки национального проекта «Жилье и городская среда» [1].

\footnotetext{
${ }^{1}$ Исследование выполнено при финансовой поддержке гранта Президента Российской Федерации для молодых ученых кандидатов наук № МК-5512.2021.1.5 
Исследователи [3], описывая особенности реализации федерального проекта в Ижевске и ряде других городов, выделили ряд проблем, с которыми сталкиваются власти на местах. В частности, одной из сложностей названа необходимость составления региональных и муниципальных программ в сжатые сроки, что влечет за собой не всегда удачный и адекватный выбор территорий, подлежащих благоустройству. В Тверской области региональная программа «Формирование современной городской среды» (далее - РП) на 2018-2024 годы с перечнем территорий в муниципальных образованиях принята 1 сентября 2017 г. [5]. Последние изменения датируются 18 сентября 2020 г., включая обновление списка подлежащих благоустройству мест.

Цель данного исследования - проанализировать участие малых городов региона в этой программе, рассмотрев микрогеографию проектов, a также сопоставив с другими реализуемыми мероприятиями по преобразованию городской среды. Включение городской территории в региональную программу и последующее ее благоустройство зависят от общественного обсуждения на местах - из списков дворовых и общественных мест, представленных в муниципальных программах, жители выбирают приоритетные путем голосования. Таким образом, анализ позволит сделать выводы, пусть и опосредованно, об активности горожан и об их видении ключевых городских преобразований.

Материалы и методы исследования. Информационной базой исследования стали упоминавшаяся выше региональная программа Тверской области, материалы Всероссийского конкурса лучших проектов создания комфортной городской среды (далее - Конкурс), списки участников Программы поддержки местных инициатив (далее - ППМИ).

Объектами исследования выступили 7 малых городов Тверской области - Бежецк, Бологое, Калязин, Кашин, Кувшиново, Торжок, Торопец. Эти города различаются по возрасту и людности. Объединяет их то, что все они являлись участниками Конкурса, за исключениями г. Бологое и г. Кувшиново - еще и победителями. Выводы работы основаны не только на анализе документов, но и на материалах собственных полевых исследований, проведенных в этих малых городах.

Результаты исследования и их обсуждение. Анализ перечня территорий, включенных в региональную программу, показал неравнозначность участия городов, причем формальные критерии не всегда объясняют сложившуюся картину (табл. 1). В распределении субсидий среди муниципальных образований (MO), согласно федеральным Правилам, ключевую роль играют бюджетная обеспеченность МО и его участие в региональной программе капитального ремонта (через количество многоквартирных домов). Согласно такому подходу, закономерно было бы ожидать наибольшую активность (через число проектов) от наиболее крупных городов с 
преобладающим многоквартирным жилым фондом. Однако лидерство Кашина с максимальным числом проектов за три года свидетельствует о возможностях региона самостоятельно определять объем средств, получаемых каждым МО. Занимающий второе место по числу проектов Торжок, является самым крупным среди рассматриваемых городов. Находящийся на третьем месте г. Кувшиново - моногород, финансирование этой категории городов является обязательным.

Табличи 1

Число проектов, реализуемых в малых городах Тверской области по программе «Формирование современной городской среды»

\begin{tabular}{|l|c|c|c|c|c|c|c|c|}
\hline \multirow{2}{*}{ Город } & \multicolumn{2}{|c|}{2019} & \multicolumn{2}{c|}{2020} & \multicolumn{2}{c|}{2021} & \multicolumn{2}{c|}{ Всего } \\
\cline { 2 - 10 } & ДТ $^{*}$ & ОТ $^{* *}$ & ДТ & ОТ & ДТ & ОТ & ДТ & ОТ \\
\hline Бежецк & 0 & 3 & 0 & 4 & 0 & 3 & 0 & 10 \\
\hline Бологое & 0 & 2 & 0 & 3 & 0 & 2 & 0 & 7 \\
\hline Калязин & 2 & 1 & 1 & 2 & 0 & 1 & 3 & 4 \\
\hline Кашин & 2 & 2 & 2 & 5 & 4 & 4 & 8 & 11 \\
\hline Кувшиново & 2 & 1 & 3 & 1 & 3 & 1 & 8 & 3 \\
\hline Торжок & 9 & 0 & 5 & 1 & 0 & 2 & 14 & 3 \\
\hline Торопец & 1 & 1 & 2 & 2 & 1 & 1 & 4 & 4 \\
\hline Всего & 16 & 10 & 13 & 18 & 8 & 14 & 37 & 42 \\
\hline
\end{tabular}

Интерес представляют не только различия в количестве проектов, но и в их типах - дворовые (ДТ) или общественные территории (ОT) благоустраиваются. Можно предположить, что там, где число ДТ больше - сильна роль локальных сообществ, продвигающих свои дворы. Там, где преобладают ОТ, вероятно, значима роль местных администраций, для которых в приоритете благоустройство общественно значимых мест.

Примером города, где реализуются, в первую очередь, локальные (дворовые) инициативы, выступает Торжок - из 17 проектов по региональной программе лишь 3 предполагают обустройство общественных мест. При этом два из трех - проекты, посвященные одной территории (скверу на руч. Здоровце). С одной стороны, такие результаты показывают активность местных (дворовых) «команд» в лице управляющих компаний, товариществ собственников жилья, депутатов, жильцов. С другой стороны, отсутствие целостной стратегии по благоустройству общественных пространств в Торжке - историческом городе, ценном в туристическом плане - настораживает.

Противоположные примеры - Бежецк и Кашин, где, наоборот, основной акцент сделан на преображении именно общественных пространств. Различия у двух городов следующие - если Кашин 
последовательно реализует проекты в центральной части города, то проекты в Бежецке, в силу его большей людности и площади, рассредоточены по городской территории. В г. Бологое, где также преобладают проекты ОТ, благодаря программе осуществлены масштабные проекты по обновлению набережной и парка «Березовая роща».

Еще одной программой, рассматриваемой в качестве инструмента по благоустройству городских территорий, является программа поддержки местных инициатив (далее - ППМИ). Основанная на принципе соучастия и софинансирования различных инфраструктурных проектов, ППМИ действует в Тверской области с 2013 г. Направления ППМИ шире, чем благоустройство, общие сведения о ее многолетней работе в регионе, а также особенности реализации в городах и сельской местности были освещены ранее в серии публикаций $[7,8]$. Здесь будут затронуты лишь те аспекты, которые связаны с обустройством пространств в выбранных городах.

В целом, благоустройство территорий является распространенным направлением работы по ППМИ в городах (табл.2). Это их отличает от сельской местности, где тематика проектов более разнообразна.

Табли ияа 2

Число проектов, реализованных в малых городах Тверской области по программе поддержки местных инициатив

\begin{tabular}{|l|c|c|}
\hline \multirow{2}{*}{ Город } & Всего реализованных проектов ППМИ (2013-2021) \\
\cline { 2 - 3 } & всего & $\begin{array}{c}\text { из них благоустройство } \\
\text { ДТ* }{ }^{*} \text { ОТ } * *\end{array}$ \\
\hline Бежецк & 10 & 6 \\
\hline Бологое & 2 & 2 \\
\hline Калязин & 10 & 6 \\
\hline Кашин & 5 & 5 \\
\hline Кувшиново & 1 & 1 \\
\hline Торжок & 14 & 2 \\
\hline Торопец & 4 & 34 \\
\hline Всего & 46 & \\
\hline *-дворовые территории & \\
**- общественные территории
\end{tabular}

Большинство рассматриваемых проектов ППМИ - это обустройство общественных мест, часто реализуемых последовательно в течение нескольких лет. Например, в Бежецке - это благоустройство липовой аллеи по ул. Л. Толстого, в Калязине - городского парка, в Кашине - набережной р. Кашинки. Среди всех городов выделяется Торжок, где ППМИ использована в качестве инструмента по обновлению 
только дворовых территорий, главным образом - по установке там детских площадок. Как и в случае с региональной программой по формированию комфортной среды, в Торжке наблюдается некоторое смещение фокуса с общественных территорий на дворовые.

Всероссийский конкурс лучших проектов создания комфортной городской среды - инструмент с самым большим объемом средств, выделяемых для преобразования городов. Как следствие, и число проектов, на которые выделяются субсидии - меньше. Из семи рассматриваемых городов пять стали победителями Конкурса: Торжок - в 2018, Бежецк, Калязин, Торопец - в 2020, Кашин - в 2021. Всего в России за 3 года (2018-2021) было проведено 5 конкурсов, 500 проектов были объявлены победителями, суммарно на их финансирование было выделено из федерального бюджета около 30 млрд. рублей [2].

Помимо различий в активности использования различных инструментов по благоустройству территорий, для городов характерны разные территориальные стратегии. Разделив городское пространство на условные части - центр, полупериферию и периферию, можно выделить несколько моделей реализации проектов по благоустройству. Максимальное число вариантов у таких моделей - шесть, в зависимости от того, где реализуется большая часть проектов или где их почти нет.

Для рассматриваемых городов характерны три варианта территориальных стратегий благоустройства (табл. 3). Самый популярный вариант - максимальное число проектов в центре города, чуть меньше на полупериферии, еще меньше или нет совсем - на периферии. Такая стратегия отмечена не только в малых исторических городах - Торопце, Кашине, Калязине - но и в г. Бологое. Это свидетельство административного влияния на выбор территорий под благоустройство, так как интересы местной власти, в первую очередь, связаны с преобразованием центральной части города. В Бежецке и Кувшинове основной фокус благоустройства направлен на благоустройство полупериферии, где размещены основные жилые массивы.

Табличе 3

Варианты территориальных стратегий благоустройства

\begin{tabular}{|l|c|c|c|}
\hline \multirow{2}{*}{\multicolumn{1}{|c|}{ Город }} & \multicolumn{3}{|c|}{ Число проектов* } \\
\cline { 2 - 4 } & Центр & Полупериферия & Периферия \\
\hline Бежецк & $\operatorname{med}$ & $\max$ & $\min$ \\
\hline Бологое & $\max$ & $\operatorname{med}$ & $\min$ \\
\hline Калязин & $\max$ & $\operatorname{med}$ & $\min$ \\
\hline Кашин & $\max$ & $\max$ & $\min$ \\
\hline Кувшиново & $\min$ & $\operatorname{med}$ & $\max$ \\
\hline Торжок & $\max$ & $\operatorname{med}$ & $\min$ \\
\hline Торопец & \multicolumn{2}{|c|}{ * мах - максимальное, $\operatorname{med}-$ среднее, $\min -$ минимальное }
\end{tabular}


Торжок стал примером территориальной «инверсии» в подходе к благоустройству. Здесь большая часть проектов (преимущественно обустройство дворов) реализована в жилых кварталах на периферии. С одной стороны, это может быть проявлением локальной активности. С другой - результатом лоббистской деятельности управляющих компаний и местных депутатов.

Графически выявленные модели можно представить следующим образом (рис.). Для обозначения зон города (центра, полупериферии, периферии) использованы традиционные для географии кольца. Различия по числу проектов отражены неодинаковым количеством точек. Число последних, как и их расположение, условно, оно призвано показать различия между зонами в разных моделях. В реальности возможны некоторые отклонения от схемы, например, в Торопце и Калязине нет проектов благоустройства на периферии вовсе. Не все города можно легко разделить на концентрические окружности, и в сложных случаях - в рассредоточенных городах Кувшиново и Бологое - деление учитывало сложную морфологию пространства.

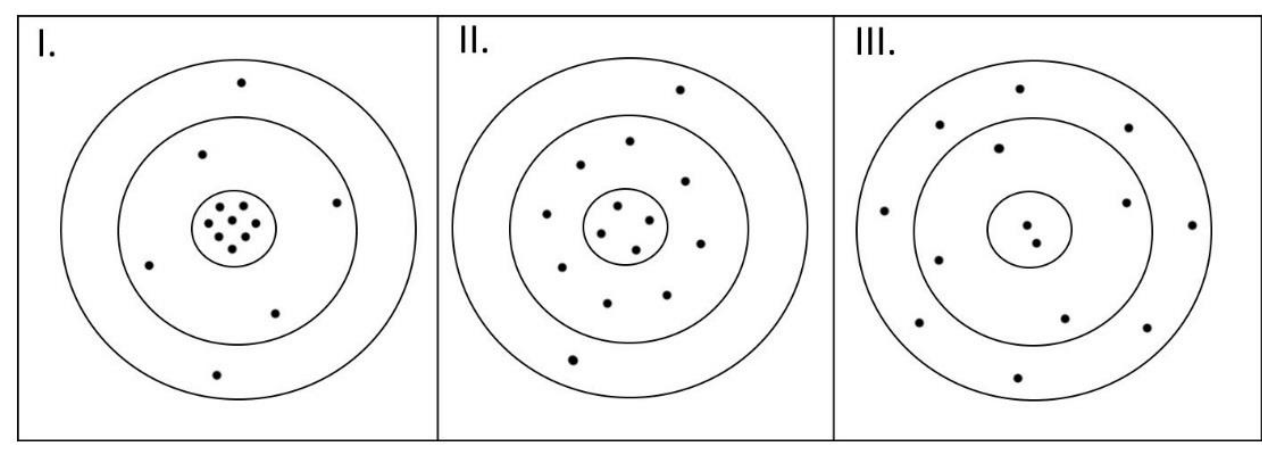

Р и с. Территориальные модели благоустройства: I - центральная, II - полупериферийная, III - периферийная (точками показано условное число проектов)

Выводы. Проблема благоустройства в городах многогранна. С появлением в федеральной повестке задачи преобразования городской среды малые города попали в сферу пристального внимания разных специалистов. В данной работе рассмотрены количественные итоги участия некоторых городов Тверской области в различных программах благоустройства (институциональный аспект). За рамками исследования остались вопросы соучастия жителей в проектировании городских изменений [6], сохранения аутентичности преобразованных пространств [4] и многие другие темы. Основной акцент сделан на микрогеографии реализованных проектов (территориальный аспект).

Рассматриваемые города различаются как в активности использования имеющихся в арсенале у муниципалитета инструментов, 
так и в территориальном выражении результатов их применения. Предложенные графические модели отражают разные стратегии благоустройства: постепенное (иногда в 2-3 очереди) благоустройство знаковых, но запустевших, общественных территорий, преимущественно в центре города; обустройство старых или создание новых мест внутри жилых массивов; хаотичное благоустройство, главным образом, дворовых территорий в периферийных районах.

\section{Список литературы}

1. Актуальные вопросы реализации федерального проекта «Формирование комфортной городской среды». URL: http://council.gov.ru/activity/activities/roundtables/128390/\#_ftn2.

2. Всероссийский конкурс лучших проектов создания комфортной городской среды. URL: https://konkurs.gorodsreda.ru/.

3. Дмитриева Н.Н., Ипатова Т.М. Формирование комфортной городской среды как стратегическое направление развитие проекта «ЖКХ и городская среда» // Социально-экономическое управление: теория и практика. - 2018. - № 1. - С. 95-98.

4. Зукин Ш. Обнаженный город. Смерть и жизнь аутентичных городских пространств / под науч. ред. В. Данилова. - М.: Изд-во Института Гайдара, 2019. - 360 с.

5. Региональная программа Тверской области «Формирование современной городской среды» на 2018-2024 годы. URL: https://docs.cntd.ru/document/450328264.

6. Санофф Г. Соучаствующее проектирование. Практики общественного участия в формировании среды больших и малых городов / ред. Н. Снигирева, Д. Смирнов. Вологда: Проектная группа 8. $-2015 .-170 \mathrm{c}$.

7. Смирнова А.А. Местные инициативы в малых городах и сельской местности Тверской области // Пространственная организация общества: теория, методология, практика / под ред. Т.В. Субботиной, Л.Б. Чупиной. - Пермь: ПГНИУ, 2018. C. 347-350.

8. Смирнова А.А. Свет, вода и детские площадки: проекты местных инициатив в Тверской области как отражение проблем территории // Крестьяноведение. - 2020. - Т. 5. - № 2. - С. 151-158. 


\title{
IMPROVEMENT OF PUBLIC SPACES IN SMALL CITIES OF TVER REGION: TERRITORIAL AND INSTITUTIONAL ASPECTS
}

\author{
I.P. Smirnov, A.A. Smirnova
}

Tver State University, Tver

The article is devoted to the problem of the improvement of public spaces in small cities. On the example of seven small cities of the Tver region, the quantitative results of their participation in various improvement programs (institutional aspect) are considered, as well as an analysis of the microgeography of the implemented projects (territorial aspect). The regional program of the Tver region on the formation of a comfortable urban environment, the Program to Support Local Initiatives, the All-Russian Competition of the Best Projects for Creating a Comfortable Urban Environment were selected as the improvement tools. Cities differ in the activity of using the named programs. Differentiation of different zones of the city - center, semi-periphery, periphery - according to the number of implemented projects was also noted. Three territorial improvement models have been proposed, depending on which part of the city is where most of the projects are concentrated.

Keywords: small cities, Tver region, improvement of public spaces, comfortable urban environment, program to support local initiatives

\section{Об авторах:}

СМИРНОВ Илья Петрович - к.г.н., доцент кафедры социальноэкономической географии и территориального планирования Тверского государственного университета, e-mail: Smirnov.IP@tversu.ru.

СМИРНОВА Александра Андреевна - к.г.н., доцент кафедры социально-экономической географии и территориального планирования Тверского государственного университета, e-mail: Fomkina.AA@tversu.ru. 